\title{
Bathymetry and Geological Setting of the South Sandwich Islands Volcanic Arc
}

Philip T. Leat ${ }^{1,2}$, Peter T. Fretwell ${ }^{1}$, Alex J. Tate ${ }^{1}$, Robert D. Larter ${ }^{1}$, Tara J. Martin ${ }^{1,3}$, John L. Smellie ${ }^{2}$, Wilfried Jokat ${ }^{4}$, and Gerhard Bohrmann ${ }^{5}$

1 British Antarctic Survey, High Cross, Madingley Road, Cambridge CB24 9BA, UK ptle@bas.ac.uk

2 Department of Geology, University of Leicester, University Road, Leicester, LE1 7RH, UK jls55@le.ac.uk

3 CSIRO GPO Box 1538, Hobart, Tasmania, 7001, Australia T.Martin@csiro.au

4 Alfred Wegener Institute Helmholtz Center for Polar and Marine Research, Columbusstrasse, D27568 Bremerhaven and the University of Bremen, Germany Wilfried.Jokat@awi.de

5 MARUM Center for Marine Environmental Sciences, University of Bremen, Leobener Strasse, D8359 Bremen, Germany gbohrmann@marum.de 


\begin{abstract}
The South Sandwich Islands and associated seamounts constitute the volcanic arc of an active subduction system situated in the South Atlantic. We introduce a map of the bathymetry and geological setting of the South Sandwich Islands and the associated East Scotia Ridge back-arc spreading centre that consists of two sides; side 1, a regional overview of the volcanic arc, trench and back-arc, and side 2, detailed maps of the individual islands. Side 1 displays the bathymetry at scale 1:750 000 of the intra-oceanic, largely submarine South Sandwich arc, the back-arc system and other tectonic boundaries of the subduction system. Satellite images of the islands on side 2 are at scales of 1:50 000 and 1:25 000 with contours and main volcanological features indicated. These maps are the first detailed topological and bathymetric maps of the area. The islands are entirely volcanic in origin, and most have been volcanically or fumarolically active in historic times. Many of the islands are ice-covered, and the map forms a baseline for future glaciological changes caused by volcanic activities and climate change. The back-arc spreading centre consists of nine segments, most of which have rift-like morphologies.
\end{abstract}

Key words: topographical mapping, East Scotia Ridge, subduction, submarine volcanism, data compilation

Running Header: South Sandwich Islands Volcanic Arc 


\section{Introduction}

Side 1

The map covers the area of the South Sandwich subduction system situated in the East Scotia Sea (Fig. 1), in the South Atlantic, between ca. $55.1^{\circ}$ and $61.9^{\circ} \mathrm{S}$, and $24^{\circ}$ and $32^{\circ} \mathrm{W}$. The main features of the tectonically and magmatically active subduction system covered by the map are the South Sandwich Trench, the South Sandwich volcanic arc, which includes the South Sandwich Islands, and the East Scotia Ridge back-arc spreading centre (Livermore et al. 1997, Fretzdorff et al. 2002, Larter et al. 2003, Leat et al. 2003). The South Sandwich Islands are the emergent parts of volcanoes forming the volcanic arc of the subduction system. The subduction system is a tectonically active part of the Scotia Sea, a compact ocean gateway region of global significance for interactions between tectonics, oceanographic flow, climate and biodiversity during Cenozoic to Recent times (Dalziel et al. 2013, Eagles \& Jokat 2014, Maldonado et al. 2015). The South Sandwich Islands are situated to the south of the Antarctic Circumpolar Current, and the bathymetry of the subduction system strongly influences major oceanographic flows (Fig. 1). Circumpolar Deep Water (CDW) is deflected north by the island chain to flow northwards through the East Scotia Sea and through the Georgia Passage bathymetric low between South Georgia and the South Sandwich Islands (Naveira Garabato et al. 2002). The deeper Weddell Sea Deep Water (WSDW) flows north through the East Scotia Sea and north along the South Sandwich Trench (Orsi et al. 1999, Naveira Garabato et al. 2002).The climate of the islands is polar (maritime Antarctic) and the islands are remote, infrequently visited and currently uninhabited. The islands are administered as part of the South Georgia and South Sandwich Islands UK Overseas Territory.

The tectonic setting of the arc is relatively simple. The volcanic arc is situated on the South Sandwich plate, or Sandwich plate, and the eastern margin of this plate is formed by the South Sandwich Trench, where South American oceanic plate is being subducted to the west at a rate of 65-78 $\mathrm{mm}$ per year (Smalley et al. 2007). The age of the subducting ocean crust ranges from about 27 million years old in the south to about 80 million years old in the north (Barker 1995). Nearly all the sediment arriving at the trench is subducted, and there is a very small accretionary frontal prism (Vanneste \& Larter 2002). Multi-channel seismic reflection profiles acquired during the 1997 British Antarctic Survey (BAS) Sandwich Lithospheric and Crustal Experiment (SLICE; Larter et al. 1998) reveal extensional structures at shallow crustal depth in the upper and mid fore-arc, suggesting that compressional stress associated with underthrusting of the South American plate is restricted to a narrow zone in the lower fore-arc (Vanneste et al. 2002). Teleseismic earthquake data are consistent with this interpretation, with relatively little seismic activity recorded beneath the arc and upper fore-arc and most mid-fore-arc activity likely related to thrusting along the plate interface. The potential of the subduction zone for producing giant earthquakes is largely unknown, but such earthquakes represent a tsunami hazard in the South Atlantic (Okal \& Hartnady 2009). At the north end of the trench, the subducting plate is being torn at depth along an east-west fracture (Forsyth 1975), causing an earthquake cluster. The south end of the trench is aligned with the South Sandwich Fracture Zone that forms part of the South America-Antarctica plate boundary. The East Scotia Ridge spreading centre forms the western margin of the Sandwich plate.

The active volcanic arc is built largely on oceanic crust that formed at this back-arc spreading centre (Larter et al. 2003). Three dredges from around $56.1^{\circ} \mathrm{S}, 26.2^{\circ} \mathrm{W}$ (Barker 1995) at depths of $4100-3100$ $\mathrm{m}$ on the southeast part of a fore-arc high northeast of Zavodovski Island yielded, peridotites interpreted to represent ocean crust of the Sandwich plate modified by metasomatic processes associated with subduction at the South Sandwich Trench (Pearce et al. 2000). Evidence for faulting and tectonic erosion along the fore-arc (Vanneste \& Larter 2002) is consistent with tectonic exhumation of the peridotites. Volcanic samples dredged from the east flank of Montagu Bank yielded K-Ar ages of 28-32 Ma, indicating that this part of the fore-arc is much older than the active volcanic arc (Barker 1995). Possible structural connections of Montagu Bank with fore-arc high blocks to the south are consistent with the existence of volcanic or continental crust that predates 
oceanic crust generated at the East Scotia Ridge underlying the southern part of the volcanic arc (Leat et al. 2013).

The submarine parts of the volcanoes of the volcanic arc have bathymetric features that have been interpreted as evidence for both constructional and erosional processes (Leat et al. 2010, Leat et al. 2013), including submarine volcanism, landslide events forming mass transport deposits and slumps. Transport of sediment from the shallow shelves around the islands to the deeper flanks was by mass flows and turbidites, forming large channel systems and sediment wave fields. The volcanic seamounts locally have a rich benthic fauna (Kaiser et al. 2008), and there are chemosynthetic communities associated with submarine hydrothermal vents (e.g. Boschen et al. 2013).

\section{Side 2}

Side 2 of the map concentrates on the topography and geology of the islands themselves. Previously the islands were very poorly mapped. The only references to the topography of the islands were a series of UK Antarctic Place-names Committee sheets constructed from sketch surveys and BAS scientific reports from the 1960s and 1970s (Holdgate \& Baker 1979, unpublished UK Antarctic Placenames Committee sheets Misc 77-79), and UK Admiralty Charts (e.g. Hydrographic Office, 2003). No trigonometric survey was ever completed of the islands and the positional accuracy of both the topography and the coastline was inaccurate (Patrick \& Smellie, 2013). Indeed the positional error of the location of the islands has caused problems integrating them into global datasets; several of the islands were mis-positioned by up to three kilometres. This lack of mapping has led to some of the islands being missed from global datasets especially those using automated processing based on global topographic compilations. One example of this is the global compilation of the ETOPO2 digital elevation model http://www.ngdc.noaa.gov/mgg/global/etopo2.html which misses several of the islands, even though some of them reach heights of over $1000 \mathrm{~m}$.

Geologically the South Sandwich Islands are the subaerial parts of a volcanic arc and are entirely composed of volcanic rocks and associated pyroclastic and volcaniclastic deposits (Holdgate \& Baker 1979, Smellie et al. 1998, Leat et al. 2003). The volcanoes are important sources of tephras in East Antarctic ice and marine sediments in the Atlantic sector of the Southern Ocean (Smellie 1999, Narcisi et al. 2010). The extent of ice-cover on the islands increases with latitude and height, and the large southern Islands, Saunders, Montagu, Bristol, and Cook and Thule islands of the Southern Thule group, are heavily glacierized. Smaller, more local ice caps occur on the northern islands Zavodovski, Visokoi and Candlemas. The islands are poorly vegetated, the flora being dominated by mosses, lichens and liverworts (Convey et al. 2000) and host abundant sea bird colonies, notably penguins.

\section{Methods}

The 1:750 000 bathymetry map (side 1 ) was compiled from a variety of different data sources (Table 1; Fig. 2). The primary data are multibeam swath bathymetry collected from scientific cruises undertaken by British Antarctic Survey (BAS), Alfred Wegener Institute (AWI) and Center for Marine and Environmental Sciences (MARUM), University of Bremen. This is supplemented by older data from a BAS towed sonar survey (MR1) and single-beam data collected by scientific surveys and commercial fishing vessels. Where no data existed from these sources, global compilations from the General Bathymetric Chart of the Oceans (GEBCO) and, below $60^{\circ}$ South, the International Bathymetric Chart of the Southern Ocean (IBCSO) were used; both these data sets use satellite altimetry in areas where data are sparse.

The new digital elevation model was gridded in a similar way to previous grids (Fretwell et al. 2008, Dickens et al. 2014). Gridded datasets were resampled to $200 \mathrm{~m}$ resolution and then converted to 
point data. These points were then given a quality hierarchy - multibeam swath being the highest, then towed data, singlebeam and finally gridded GEBCO and IBSCO data. The data were then regridded using the Topogrid algorithm in ArcGIS using the hierarchy to prioritize the data. The resulting grid was then checked for errors such as spikes and holes. Where identified, these were removed from the point datasets and the data were re-gridded. This iterative process was conducted until a clean combined dataset was produced.

On land raw ASTER GDEM grids were cleaned and merged with pre-existing survey data to create new digital elevation models for each island. The bathymetry and elevation dataset was merged and gridded using ArcGIS 10. Oblique views were created using Fledermaus software.

Earthquake data were extracted from the Centennial Catalogue (Engdahl \& Villaseñor 2002). Filtering parameters, to identify the events with most reliable depths, were: 1964-2008; open azimuth (asol) < 180 degrees; solution types DEQ, BEQ and FEQ. These earthquake data were supplemented for the area west of $29^{\circ} \mathrm{W}$ by data from the EHB Bulletin (http://www.isc.ac.uk/ehbbulletin/). The earthquake data, and their relationship to magnetic data and plate boundaries, are summarised in Fig. 3. On the map, circles denote earthquake epicentres, with the size of the circle referring to the magnitude of the quake, and colour indicating source depth, with red circles denoting deep quakes and green circles denoting shallow quakes. Magnetic lineations were drawn from the previous compilation of Larter et al. (2003). Relative tectonic motions of plates were calculated from GPS-constrained present day plate motions (Smalley et al. 2007).

Satellite images of the islands (side 2) were acquired from the Digital Globe archive (data sources provided on the map). Multiple images have been merged for some islands where cloud cover obscured parts of images to give a seamless representation of the island topography. Contours were derived from new digital elevation models created specifically for the map and are drawn at $200 \mathrm{~m}$ intervals. The digital elevation models were formulated from a combination of cleaned GDEM data and previous air photography surveys (Holdgate \& Baker 1979). In gaps where data were insufficient these data were supplemented by interpolation from VHR satellite imagery. Coastlines were digitized from QuickBird2 and Worldview1 satellite images and are considered accurate to within 10 metres. Details of the satellite images used are recorded on the map.

Volcanological information on the islands (side 2 ) was compiled from various sources. Because of the remote location, historical volcanological observations from the islands are rare. The most recent field survey covering all the islands was obtained during the SLICE project in 1997 (Larter et al. 1998, Smellie et al. 1998). The summit features on Visokoi Island were interpreted from the satellite images. Detail for the summit of Mount Michael on Saunders Island is taken from interpretation of recent eruptions from satellite data (Lachlan-Cope et al. 2001, Patrick \& Smellie 2013). Detail for the recent eruption of Mount Belinda, Montagu Island (2001-2007) is also mainly satellite-based (Patrick et al. 2005, Patrick \& Smellie 2013), although the eruption site and the lava flow that reached the north coast at Pounced Point were also observed from ships and RAF aircraft. Current persistent fumarolic activity on the west side of Zavodovski Island, around Mount Lucifer in the northern part of Candlemas Island, and around the main crater of Bellingshausen Island is confirmed by infrequent observations from passing ships. Detail of vents and other volcanic features on Bristol and Thule Island is derived from helicopter observations in 1962, 1964 and 1997 and more recent satellite imagery (Holdgate 1963, Holdgate \& Baker 1979, Patrick \& Smellie 2013). The crater on Mount Michael, Saunders Island, intermittently contains a lava lake, identified from plume characteristics and satellite imagery (Lachlan-Cope et al. 2001).

Sea-floor hydrothermal vents have been observed on the summits of segments E2 and E9 of the back-arc spreading centre (Rogers et al. 2012). Sea floor venting has also been directly observed within both Kemp and Adventure calderas in the southern part of the South Sandwich arc (Boschen et al. 2013, Leat et al. 2013). These confirmed submarine vents are shown on the map. Temperature 
data recorded during submersible dives in Quest caldera, and on Protector Seamount and Scoresby Seamount, all in the Protector Seamounts area, provide a strong indication of active seafloor hydrothermal venting in this northern part of the arc as well (Bohrmann 2013). As these northern vents have not been confirmed by direct observation, they are not indicated on the map.

\section{Results}

The map is published by the British Antarctic Survey (BAS) as the sixth sheet of its BAS GEOMAP 2 series. (Leat et al. 2014).

The bathymetric map (side 1) shows accurately for the first time geographic relationships of the various elements of the volcanic arc - back-arc system (Fig. 4). It shows the distribution of volcanic constructs and major sedimentary processes in relation to the volcanic islands and major tectonic features. The satellite images of the islands (Side 2) show an accurate representation of the shape, position and topography of the islands and recent volcanic features in relationship to improved topographic data and current ice coverage. An example of such images is shown in Fig. 5 which depicts the topography of Saunders Island.

\section{Discussion}

\section{South Sandwich Trench}

The South Sandwich Trench is continuous from its intersection with the South Sandwich Fracture Zone to the northern part of the Sandwich plate, where it bends to the west at the plate margin along which the South American plate is being down-warped as it subducts (Forsyth 1975, Leat et al. 2004). The trench has not been well surveyed using multibeam bathymetry. It is more than $8 \mathrm{~km}$ deep in its northeast part (Barker 1995), generally shallows to the south and the slope between the volcanic arc and the trench axis steepens to the north. The new bathymetry data set provides improved resolution of the upper fore-arc structure. One fore-arc high extends from NW of Protector Shoal to the latitude of Zavodovski Island and is defined in detail for the first time by the bathymetry data (Fig. 6a). This structure trends northwest-southeast and rises to ca. $2500 \mathrm{~m}$ bsl in the south and above $1500 \mathrm{~m}$ in the north. The peridotites interpreted to sample the mantle of the Sandwich plate (Pearce et al., 2000) were dredged from the southeastern part of this fore-arc high (Fig. 6a). Between the latitudes of Zavodovski Island and Montagu Island, fore-arc highs are subdued, and there are several depressions along which sediment may be transported into the trench. The most prominent fore-arc high, Montagu Bank, is shown to be an asymmetrical structure with a steep east-facing slope. The map indicates that Montagu Bank has possible along-strike connections with other fore-arc high blocks to the east of the southern Thule-Adventure sector of the arc. Where fore-arc highs are subdued, the bathymetry detail suggests the existence of channels associated with sediment waves continuing east from close to the subaerial volcanoes toward the trench axis. An example from east of Zavodovski Island is shown in Fig. 6a, in which a large sediment wave field sourced from the east flanks of the volcanic island can be traced east along the floor of a wide bathymetric low that continues into the South Sandwich Trench around the southern end of the fore-arc high which exposes the peridotites.

\section{Volcanic arc}

Detail of the bathymetry around the seamounts and islands of the volcanic arc has been described previously (Leat et al. 2010, Leat et al. 2013). The arc is relatively free of complicating factors such as intra-arc rifting, the presence of remnant arcs, or collision with seamount chains, oceanic plateaux or ridges. The volcanic arc consists of eight main volcanic edifices, all having multiphase structure and 
several having associated seamounts. These main edifices are, from north to south, Zavodovski, Visokoi, the Candlemas group, Saunders, Montagu, Bristol, Southern Thule and the Kemp and Adventure group. Compositionally, the volcanoes are dominated by basalts and basaltic andesites, with minor andesites, dacites and rhyolites. Magma generation was caused by subduction of the South American plate beneath the arc, producing a silica-oversaturated, tholeiitic series (Pearce et al. 1995, Leat et al. 2003, Leat et al. 2004, Barry et al. 2006).

At the northern end of the arc, a group of seamounts cluster around Protector Shoal and geochemically form part of the volcanic arc. At the southern end of the arc, Nelson Seamount is situated $65 \mathrm{~km}$ south of Kemp Caldera and southwest of the non-volcanic Tyrell Bank, and represents the southernmost extent of recent volcanism in the South Sandwich arc, although its dacites have geochemical compositions distinct from those of the main volcanic arc (Leat et al. 2004).

There are three northeast-southwest trending rear-arc seamount chains that extend from the southeast of Zavodovski Island and from the north and south of the Saunders edifice some 38-60 km toward the back-arc. There are no obvious correlations of these chains with back-arc structure (Fig. 4).

Submarine parts of the volcanoes of the volcanic arc are characterized by both constructional and mass-wasting processes (Leat et al. 2010, Leat et al. 2013). Submarine constructional volcanic features consist of seamounts and topographically more subdued flank eruptions as illustrated by the area around Saunders Island (Fig. 6b). Evidence for mass-wasting includes embayments indicating numerous collapse events affecting sectors of volcanoes' flanks and erosional gullies which probably exploited and enlarged collapse scars. Examples of probable collapse scars and erosional gullies are shown around Zavodovski, Visokoi and Saunders Islands in Fig. 6, but they occur on all the main volcanic edifices. Submarine flanks of most of the emergent volcanoes have prominent wave-like surfaces interpreted as sediment wave fields formed by down-slope transport of volcaniclastic sediments as mass-flows and turbidites (Leat et al. 2010). The sediment wave fields are observed to originate dominantly from erosional gullies which cut down through the edge of shallow shelves around the emergent volcanoes as seen east of both Zavodovski and Saunders islands (Figs. 6a,b) indicating that the source of the transported sediments is volcaniclastic material generated from the subaerial volcanoes and their shore-lines. Several slump structures have been identified, and some sediment wave fields are thought to have been modified by slumping (Leat et al. 2010, Leat et al. 2013). On the western flank of the arc, a turbidite apron up to $1 \mathrm{~km}$ thick, probably representing the distal part of the volcaniclastic sedimentation, overlies oceanic basement and thins towards the East Scotia Ridge (Vanneste et al. 2002).

\section{Back-arc spreading centre}

The East Scotia Ridge is a back-arc spreading centre along which the Sandwich plate is separating from the Scotia plate (Livermore et al. 1997). The current full spreading rate is $59-68 \mathrm{~mm}$ per year (Smalley et al. 2007). Marine magnetic anomalies on the western flank of the spreading centre record a history of continuous spreading that extends to at least $15 \mathrm{Ma}$ (magnetic anomaly 5B), and reveal stepped increases in spreading rates since $6 \mathrm{Ma}$ (Larter et al. 2003). Magnetic lineations displayed in the map show that the northern part of the volcanic arc is built largely of oceanic crust formed at this spreading centre about 10 million years ago (Larter et al. 2003).

The main spreading centre consists of nine well-defined segments from E1 where the spreading centre meets the trench in the north, to $\mathrm{E} 9$ in the south. The bathymetry indicates that there are no stable transform fault offsets between segments, and segment boundaries are thought to be migrating ridge offsets (Livermore et al. 1997, Larter et al. 2003). Central segments E3 to E8 are riftlike, with axial depressions, and segments E2 and E9, near the north and south ends of the spreading 
centre respectively, have positive axial topography resulting from enhanced mantle melting (Livermore et al. 1997, Leat et al. 2004). Seismic reflection data have been used to infer a one kmwide magma lens three $\mathrm{km}$ beneath the sea floor in the central part of segment E2 (Livermore et al. 1997).

Compositions in most segments are basaltic, but segment E2 has erupted basaltic andesite and rare andesite. The mantle sources of the back-arc magmatism were geochemically varied and related to geometry of mantle flow and distance from the trench (Leat et al. 2004). Most of the central segments have erupted compositions close to mid-ocean ridge basalts (MORB). Other identified components are an enriched mantle source thought to be mantle flowing into the back-arc around the slab edges and a component modified by fluids derived from the subducting slab (Fretzdorff et al. 2002, Leat et al. 2004). Segment E2 has a high magma production rate, and had enriched and subduction-modified mantle sources consistent with its position close to the slab edge. Segment E9, also close to the slab edge, had an enriched mantle source. Segments E8 and E4 were significantly modified by slab-derived fluids. Other segments are dominated by MORB compositions.

\section{Conclusions}

The map shows both the bathymetry of the South Sandwich subduction system, and the topography and main volcanic features of the islands of the volcanic arc. The bathymetric map includes highresolution coverage of the submarine part of the volcanic arc and of the back-arc spreading centre. The map provides a resource for future sampling and experiments in this outstanding natural laboratory. Future projects in the South Sandwich Islands region are likely to include investigations of submarine hydrothermal vents and their biology, submarine observations of volcanic and sedimentary process, and sampling to investigate the generation of magmatism in the subduction system. The map also provides a base for assessing future geological, volcanological and glaciological changes.

\section{Acknowledgements}

This study is part of the British Antarctic Survey Polar Science for Planet Earth Programme funded by The Natural Environment Research Council. We are grateful to Graham Eagles, an anonymous reviewer and David Walton for comments that helped improve the paper.

\section{Supplemental material}

The map and data files from which is was derived are available online at URL:

http://dx.doi.org/10.5285/b8143952-421c-4544-8437-58f339253d30 


\section{References}

BARKER, P.F. 1995. Tectonic framework of the East Scotia Sea. In Taylor B., ed. Backarc basins: tectonics and magmatism. New York: Plenum Press, pp. 281-314.

BarRy, T.L., Pearce, J.A., Leat, P.T., Millar, I.L. \& Le Roex, A.P. 2006. Hf isotope evidence for selective mobility of high-field-strength elements in a subduction setting: South Sandwich Islands. Earth and Planetary Science Letters, 252, 223-244.

BohrmAnN, G. (ed.) 2013. The Expedition of the Research Vessel "Polarstern" to the Antarctic in 2013 (ANT-XXIX/4). Berichte zur Polar- und Meeresforschung, 668, 169pp.

BOSCHEN, R.E., TYLER, P.A. \& COPLEY, J.T. 2013. Distribution, population structure, reproduction and diet of Ophiolimna antarctica (Lyman, 1879) from Kemp Caldera in the Southern Ocean. Deep Sea Research Part II, 92, 27-35.

Convey, P., LeWIS SMITH, R.I., Hodgson, D.A. \& PEAT, H.J. 2000. The flora of the South Sandwich Islands, with particular reference to the influence of geothermal heating. Journal of Biogeography, 27, 1279-1295.

Dalziel, I.W.D., LawVer, L.A., Pearce, J.A., Barker, P.F., Hastie, A.R., Barfod, D.N., SChenke, H-W. \& DAVIS, M.B. 2013. A potential barrier to Antarctic circumpolar flow until the late Miocene? Geology, 41,767-793.

Dickens, W.A., Graham A.G.C., SMith, J.A., DOWDesWell, J.A., LARTER, R.D., HillenBrand, C.D., TRATHAN, P.N., ARNDT, J.A. \& KUHN, G. 2014 A new bathymetric compilation for the South Orkney Islands region, Antarctic Peninsula $\left(49^{\circ}-39^{\circ} \mathrm{W}\right.$ to $\left.64^{\circ}-59^{\circ} \mathrm{S}\right)$ : insights into the glacial development of the continental shelf. Geochemistry, Geophysics, Geosystems, 15, 6, 2494-2514.

EAGLES, G. \& JOKAT, W. 2014. Tectonic reconstructions for paleobathymetry in Drake Passage. Tectonophysics, 611, 28-50.

ENGDAHL, E.R. \& VILLASEÑOR, A. 2002. Global Seismicity: 1900-1999. In Lee W.H.K., Kanamori, H., Jennings P.C. \& Kisslinger C. eds., International Handbook of Earthquake and Engineering Seismology, Academic Press, Part A, Chapter 41, pp. 665-690. http://earthquake.usgs.gov/research/data/centennial.php

FORSYTH, D.W. 1975. Fault plane solutions and tectonics of the South Atlantic and Scotia Sea. Journal of Geophysical Research, 80, 1429-1443.

Fretwell, P.T., TAte, A.J., Deen, T.J. \& BelChieR, M. 2008. Compilation of a new bathymetric dataset of South Georgia. Antarctic Science, 21, 171-174.

FReTZdorfF, S., Livermore, R.A., DeVey, C.W., LEAT, P.T. \& StofferS, P. 2002. Petrogenesis of the back-arc East Scotia Ridge, South Atlantic Ocean. Journal of Petrology, 43, 1435-1467.

HoldGate, M.W. 1963. Observations in the South Sandwich Islands, 1962. Polar Record, 11 (73), 394405.

Holdgate, M.W. \& BAKER, P.E. 1979. The South Sandwich Islands: I. General description. British Antarctic Survey Scientific Reports, No. 91, 76pp.

Hydrographic Office 2003. South Sandwich Islands, Chart No. 3593, 1:500 000, Admiralty Hydrographic Department, Taunton.

KAISER, S., BARNES, D.K.A., LINSE, K. \&, BRANDT, A. 2008. Epibenthic macrofauna associated with the shelf and slope of a young and isolated Southern Ocean island. Antarctic Science, 20, 281-290. 
LACHLAN-COPE, T., SMELLIE, J.L. \& LADKIN, R. 2001. Discovery of a recurrent lava lake on Saunders Island (South Sandwich Islands) using AVHRR imagery. Journal of Volcanology and Geothermal Research, 112, 105-116.

LARTER, R.D., KING, E.C., LeAT, P.T., ReAding, A.M., SMelLie, J.L. \& SMYthe, D.K. 1998. South Sandwich slices reveal much about arc structure, geodynamics and composition. EOS, Transactions, American Geophysical Union, 79, 281-285.

LARTER, R.D., VANNESTE, L.E., MORRIS, P. \& SMYTH, D.K. 2003. Structure and tectonic evolution of the South Sandwich arc. In Larter R.D. \& Leat P.T. eds., Intra-oceanic subduction systems: tectonic and magmatic processes. London: Geological Society Special Publications, 219, pp. 255-284.

LEAT, P.T., DAY, S.J., TATE, A.J., MARTIN, T.J., OWEN, M.J. \& TAPPIN, D.R. 2013. Volcanic evolution of the South Sandwich volcanic arc, South Atlantic, from multibeam bathymetry. Journal of Volcanology and Geothermal Research, 265, 60-77.

Leat, P.T., Fretwell, P.T., TATe, A.J., LARTeR, R.D., MARTin, T.J., SMellie, J.L., JokAT, W. \& BohrmanN, G. 2014. Bathymetry and Geological Setting of the South Sandwich Islands Volcanic Arc (various scales), BAS GEOMAP 2 series, Sheet 6, Cambridge: British Antarctic Survey.

Leat, P.T., PeARCE, J.A., Barker, P.F., Millar, I.L., BARRY, T.L. \& LARTER, R.D. 2004. Magma genesis and mantle flow at a subducting slab edge: the South Sandwich arc-basin system. Earth and Planetary Science Letters, 227, 17-35.

Leat, P.T., SMelLie, J.L., MiLlaR, I.L. \& LARTER, R.D. 2003. Magmatism in the South Sandwich arc. In Larter R.D. \& Leat P.T. eds., Intra-oceanic subduction systems: tectonic and magmatic processes. London: Geological Society Special Publications, 219, pp. 285-313.

LEAT, P.T., TATE, A.J., TAPPIN, D.R., DAY, S.J. \& OWEN, M.J. 2010. Growth and mass wasting of volcanic centers in the northern South Sandwich arc, revealed by new multibeam mapping. Marine Geology, 275, 110-126.

LIVERMORE, R., CUNNINGHAM, A., VANNESTE, L. \& LARTER, R. 1997. Subduction influence on magma supply at the East Scotia Ridge. Earth and Planetary Science Letters, 150, 261-275.

MaLdonAdo, A., DALZIEL, I.W.D. \& LEAT, P.T. 2015. The global relevance of the Scotia arc: an introduction. Global and Planetary Change, 125, A1-A8.

NARCISI, B., PETIT, J.R. \& DELMONTE, B. 2010. Extended East Antarctic ice-core tephrostratigraphy. Quaternary Science Reviews, 29, 21-27.

NAveira Garabato, A.C., HeYwood, K.J. \& SteVens, D.P. 2002. Modification and pathways of Southern Ocean Deep Waters in the Scotia Sea. Deep Sea Research Part I, 49, 681-705.

OKAL, E.A. \& HARTNADY, C.J. 2009. The South Sandwich Islands earthquake of 27 June 1929: seismological study and inference on tsunami risk for the South Atlantic. South African Journal of Geology, 112, 359-370.

ORSI, A.H., JOHNSON, G.C. \& BULLISTER, J.L. 1999. Circulation, mixing, and production of Antarctic Bottom Water. Progress in Oceanography, 43, 55-109.

PATRICK, M.R. \& SMELLIE, J.L. 2013. A spaceborne inventory of volcanic activity in Antarctica and southern oceans, 2000-10. Antarctic Science, 25, 475-500.

Patrick, M.R., Smellie, J.L., Harris, A.J.L., Wright, R., Dean, K., Izbekov, P., Garbeil, H. \& Pilger, E. 2005. First recorded eruption of Mount Belinda volcano (Montagu Island), South Sandwich Islands. Bulletin of Volcanology, 67, 415-422. 
PeARCE, J.A., BAKER, P.E., HARVEY, P.K. \& LUfF, I.W. 1995. Geochemical evidence for subduction fluxes, mantle melting and fractional crystallization beneath the South Sandwich island arc. Journal of Petrology, 36, 1073-1109.

PearCe, J.A., BARKeR, P.F., EdWARdS, S.J., PARkinson, I.J. \& LeAT, P.T. 2000. Geochemistry and tectonic significance of peridotites from the South Sandwich arc-basin system, South Atlantic. Contributions to Mineralogy and Petrology, 139, 36-53.

Rogers, A.D., Tyler, P.A., Connelly, D.P., Copley, J.T., JAMES, R., et al. 2012. The discovery of new deepsea hydrothermal vent communities in the Southern Ocean and implications for biogeography. PLoS Biology, 10(1), e1001234. doi:10.1371/journal.pbio.1001234.

SMAlley, R., DalzIEL, I.W.D., BeVIS, M.G., KendRICK, E., StampS, D.S., KING, E.C., TAYLOR, F.W., LAURía, E., ZAKRAJSEK, A. \& PARRA, H. 2007. Scotia arc kinematics from GPS geodesy. Geophysical Research Letters, 34, L21308, doi:10.1029/2007GL031699.

SMELLIE, J.L. 1999. The upper Cenozoic tephra record in the south polar region: a review. Global and Planetary Change, 21, 51-70.

SMELLIE, J.L., MoRRIS, P., LeAT, P.T., TURNER, D.B. \& Houghton, D. 1998. Submarine caldera and other volcanic observations in Southern Thule, South Sandwich Islands. Antarctic Science, 10, 171-172.

VANNESTE, L.E. \& LARTER, R.D. 2002. Sediment subduction, subduction erosion, and strain regime in the northern South Sandwich forearc. Journal of Geophysical Research, 107(B7), 2149, doi:10.1029/2001JB000396.

VANNESTE, L.E., LARTER, R.D. \& SMYTHE, D.K. 2002. Slice of intraoceanic arc: insights from the first multichannel seismic reflection profile across the South Sandwich island arc. Geology, 30, 819822.

\section{Figure captions}

Fig. 1. Sketch bathymetric map of the South Atlantic showing predicted bathymetry based on satellite gravity and ships' soundings (shallow sea in red, deep sea in blue). Major tectonic elements after Maldonado et al. (2015). Major oceanographic fronts and flows are after Orsi et al. (1999) and Naveira Garabato et al. 2002. APR, Antarctic-Phoenix Ridge; ESR, East Scotia Ridge; SAAR, South America-Antarctic Ridge; WSR, West Scotia Ridge; SSIB, South Shetland Islands Block; ACC, Antarctic Circumpolar Current; CDW, Circumpolar Deep Water; WSDW, Weddell Sea Deep Water; SAF, Subantarctic Front; PF, Polar Front; SACCF, Southern ACC Front; SB, Southern Boundary of the ACC.

Fig. 2. Data sources for ship-derived bathymetric data used in the compilation.

Fig. 3. Tectonic overview map as shown in the on-line map. Projection is Albers Equal Area Conic. Bathymetric depths are indicated by shading; darker blue indicates deeper ocean and lighter blue shallower water. Ocean floor magnetic anomalies are after the compilation of Larter et al. (2003). Earthquake epicentres are depicted by circles, with size of circles denoting earthquake magnitude. The colour of circles indicates depth of earthquakes and is an indicative variable colour ramp, in the scale red (deep sources) to yellow-green (shallow sources). The scale is linear and earthquake depths range from 4.4 to $285 \mathrm{~km}$. 
Fig. 4. Bathymetric map of the South Sandwich arc after side 1 of the on-line map. Some detail from the on-line version has been removed or altered for clarity. The locations of areas shown in Figs. $6 a$ and $b$ are indicated.

Fig. 5. Example of a topographic map of an island as displayed on the on-line map (side 2). The example is of Saunders Island, showing the extensive permanent ice cover on the island, and ice-free areas around the coast, notably Ashen Hills in the southeast which are a group of basaltic hydromagmatic cones. Sites of recent volcanic and fumarolic activity at the summit of Mount Michael are indicated. The scale on the on-line map is 1:50 000.

Fig. 6. Illustrations of sections of the bathymetry map of the South Sandwich Islands volcanic arc (side 1) at slightly reduced scale: a. Volcanic arc and section of fore-arc and western part of the trench including Zavodovski and Visokoi islands, and $\mathbf{b}$. the volcanic arc volcano of Saunders Island and surrounding seamounts. Circles are earthquakes with radii and colours corresponding to magnitude and depth respectively; full explanation of symbols on on-line map.

\section{Author Contributions}

Bathymetric data were collected on several cruises by Leat, Tate, Larter, Martin, Jokat and Bohrmann. Bathymetric data were compiled by Fretwell, Tate and Leat. Satellite images of the islands and contours were prepared by Fretwell. Volcanological interpretations were made by Smellie and Leat. Magnetic and earthquake data were prepared by Larter. The map was prepared by Fretwell and Leat. The text of the paper was written by Leat and Fretwell with contributions from Larter and Smellie. 
Table 1

Table 1. Data sets used in the South Sandwich arc bathymetric compilation

\begin{tabular}{|c|c|c|c|c|c|}
\hline $\begin{array}{l}\text { Survey } \\
\text { Type }\end{array}$ & Vessel & Survey ID & Year & Data Source & Further information \\
\hline MBES & RRS James Clark Ross & JR149 & 2006 & BAS & https://www.bodc.ac.uk/data/information and inventories/cruise inventory/report/7932/ \\
\hline MBES & RRS James Clark Ross & JR168-167 & 2007 & BAS & https://www.bodc.ac.uk/data/information_and_inventories/cruise_inventory/report/9079/ \\
\hline MBES & RRS James Clark Ross & JR206 & 2010 & BAS & https://www.bodc.ac.uk/data/information_and_inventories/cruise_inventory/report/9971/ \\
\hline MBES & RRS James Clark Ross & JR224 & 2009 & BAS & https://www.bodc.ac.uk/data/information_and_inventories/cruise_inventory/report/9359/ \\
\hline MBES & RRS James Clark Ross & $\begin{array}{l}\text { JR239-235- } \\
236\end{array}$ & 2010 & BAS & https://www.bodc.ac.uk/data/information_and_inventories/cruise_inventory/report/9972/ \\
\hline MBES & RRS James Clark Ross & $\begin{array}{l}\text { JR259-275- } \\
255 \mathrm{~b}\end{array}$ & 2012 & BAS & https://www.bodc.ac.uk/data/information_and_inventories/cruise_inventory/report/10598/ \\
\hline MBES & RV Polarstern & ANT-IV/3 & $1985 / 1986$ & AWI & http://doi.pangaea.de/10.1594/PANGAEA.763923 \\
\hline MBES & RV Polarstern & ANT-VI/3 & $1987 / 1988$ & AWI & http://doi.pangaea.de/10.1594/PANGAEA.763882 \\
\hline MBES & RV Polarstern & ANT-VIII/3 & 1989 & AWI & http://doi.pangaea.de/10.1594/PANGAEA.767652 \\
\hline MBES & RV Polarstern & ANT-X/2 & 1992 & AWI & http://doi.pangaea.de/10.1594/PANGAEA.767517 \\
\hline MBES & RV Polarstern & ANT-X/5 & 1992 & AWI & http://doi.pangaea.de/10.1594/PANGAEA.767544 \\
\hline MBES & RV Polarstern & ANT-XIV/3 & 1997 & AWI & http://doi.pangaea.de/10.1594/PANGAEA.763232 \\
\hline MBES & RV Polarstern & ANT-XV/2 & 1997/1998 & AWI & http://doi.pangaea.de/10.1594/PANGAEA.724653 \\
\hline MBES & RV Polarstern & ANT-XIX/4 & 2002 & AWI & http://doi.pangaea.de/10.1594/PANGAEA.680790 \\
\hline MBES & RV Polarstern & ANT-XIX/5 & 2002 & AWI & http://doi.pangaea.de/10.1594/PANGAEA.701696 \\
\hline MBES & RV Polarstern & ANT-XXII/2 & $2004 / 2005$ & AWI & http://doi.pangaea.de/10.1594/PANGAEA.724659 \\
\hline MBES & RV Polarstern & ANT-XXIII/7 & 2006 & AWI & http://doi.pangaea.de/10.1594/PANGAEA.680794 \\
\hline MBES & RV Polarstern & ANT XXIX/4 & 2013 & MARUM & http://epic.awi.de/33589/1/BzPM 06682013 ANT-XXIX 4.pdf \\
\hline $\begin{array}{l}\text { HAWAll } \\
\text { MR1 }\end{array}$ & RRS James Clark Ross & JR09a & 1995 & BAS & http://www.soest.hawaii.edu/HMRG/cms/mr1-archive1995-cruises-jr9501/ \\
\hline SBES & Almirante Irizar & Al9495 & 1994/1995 & SHN & http://www.ngdc.noaa.gov/trackline/request/?surveylds=A19495 \\
\hline SBES & RV Atlantis II & A2107L06 & 1980 & WHOI & http://www.ngdc.noaa.gov/trackline/request/?surveylds=A2107L06 \\
\hline SBES & RRS Bransfield & Bran_767 & $1976 / 1977$ & BAS & http://www.ngdc.noaa.gov/trackline/request/?surveylds=BRAN_767 \\
\hline SBES & RRS Charles Darwin & CD37_889 & 1989 & BAS & http://www.ngdc.noaa.gov/trackline/request/?surveylds=CD37_889 \\
\hline SBES & RRS Discovery & D154_845 & 1985 & BAS & http://www.ngdc.noaa.gov/trackline/request/?surveylds=D154_845 \\
\hline
\end{tabular}




\begin{tabular}{|c|c|c|c|c|c|}
\hline SBES & RV Eltanin & ELT22 & 1966 & LDEO & http://www.ngdc.noaa.gov/trackline/request/?surveylds=ELT22 \\
\hline SBES & Eltanin/Orcadas & 10775 & 1975 & LDEO & http://www.ngdc.noaa.gov/trackline/request/?surveylds=10775 \\
\hline SBES & Eltanin/Orcadas & I1176 & 1976 & LDEO & http://www.ngdc.noaa.gov/trackline/request/?surveylds=l1176 \\
\hline SBES & HMS Endurance & End_690 & $1969 / 1970$ & BAS & http://www.ngdc.noaa.gov/trackline/request/?surveylds=END_690 \\
\hline SBES & HMS Endurance & End_756 & 1976 & BAS & http://www.ngdc.noaa.gov/trackline/request/?surveylds=END_756 \\
\hline SBES & HMS Endurance & End_767 & 1976/1977 & BAS & http://www.ngdc.noaa.gov/trackline/request/?surveylds=END_767 \\
\hline SBES & HMS Endurance & End_778 & 1977/1978 & BAS & http://www.ngdc.noaa.gov/trackline/request/?surveylds=END_778 \\
\hline SBES & HMS Endurance & End_967 & 1996/1997 & BAS & \\
\hline SBES & RRS Ernest Shackleton & EShack02 & 2002 & BAS & \\
\hline SBES & Islas Orcadas & 11578 & 1978 & LDEO & http://www.ngdc.noaa.gov/trackline/request/?surveylds=|1578 \\
\hline SBES & Islas Orcadas & 11678 & 1978 & LDEO & http://www.ngdc.noaa.gov/trackline/request/?surveylds=11678 \\
\hline SBES & RRS James Clark Ross & JR01 & 1991/1992 & BAS & http://www.ngdc.noaa.gov/trackline/request/?surveylds=JCR01 \\
\hline SBES & RRS James Clark Ross & JR09a & 1995 & BAS & http://www.ngdc.noaa.gov/trackline/request/?surveylds=JCR09A \\
\hline SBES & RRS James Clark Ross & JR09b & 1995 & BAS & http://www.ngdc.noaa.gov/trackline/request/?surveylds=JCR09B \\
\hline SBES & RRS James Clark Ross & JR12 & 1996 & BAS & http://www.ngdc.noaa.gov/trackline/request/?surveylds=JCR12 \\
\hline SBES & RRS James Clark Ross & JR18 & 1997 & BAS & http://www.bodc.ac.uk/data/information_and_inventories/cruise_inventory/report/6516/ \\
\hline SBES & RRS John Biscoe & Bisc_867 & 1987 & BAS & http://www.ngdc.noaa.gov/trackline/request/?surveylds=BISC_867 \\
\hline SBES & JOIDES Resolution & ODP177 & 1998 & MGDS & http://www.ngdc.noaa.gov/trackline/request/?surveylds=ODP177JR \\
\hline SBES & JOIDES Resolution & ODP178 & 1998 & MGDS & http://www.ngdc.noaa.gov/trackline/request/?surveylds=ODP178JR \\
\hline SBES & RV Nathaniel B. Palmer & NBP04-4 & 2004 & MGDS & http://www.marine-geo.org/link/entry.php?id=NBP0404 \\
\hline SBES & USNS Robert D. Conrad & C1103 & 1967 & MGDS & http://www.marine-geo.org/tools/search/entry.php?id=RC1103 \\
\hline SBES & San Aspiring & N/A & 2011 & $\begin{array}{l}\text { Sanford } \\
\text { Limited (NZ) }\end{array}$ & Fisheries bathymetry data - http://www.sanford.co.nz/ \\
\hline SBES & RV Vema & V1409 & 1958 & LDEO & http://www.ngdc.noaa.gov/trackline/request/?surveylds=V1409 \\
\hline
\end{tabular}

MBES, Multi Beam Echo Sounder; SBES, Single Beam Echo Sounder; HAWAII MR1 - HIG, Hawai'i Institute of Geophysics and Planetology, Acoustic Wide Angle Imaging Instrument, Mapping Researcher 1. BAS, British Antarctic Survey, UK; AWI, Alfred Wegner Institute, Germany; MARUM, Center for Marine Environmental Sciences, University of Bremen, Germany; SHN, Servicio de Hidrografia Naval, Argentina; WHOI, Woods Hole Oceanographic Institution, USA; LDEO, Lamont Doherty Earth Observatory, USA; MGDS, Marine Geoscience Data System, USA. 


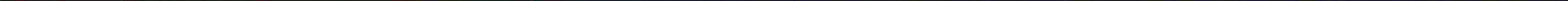




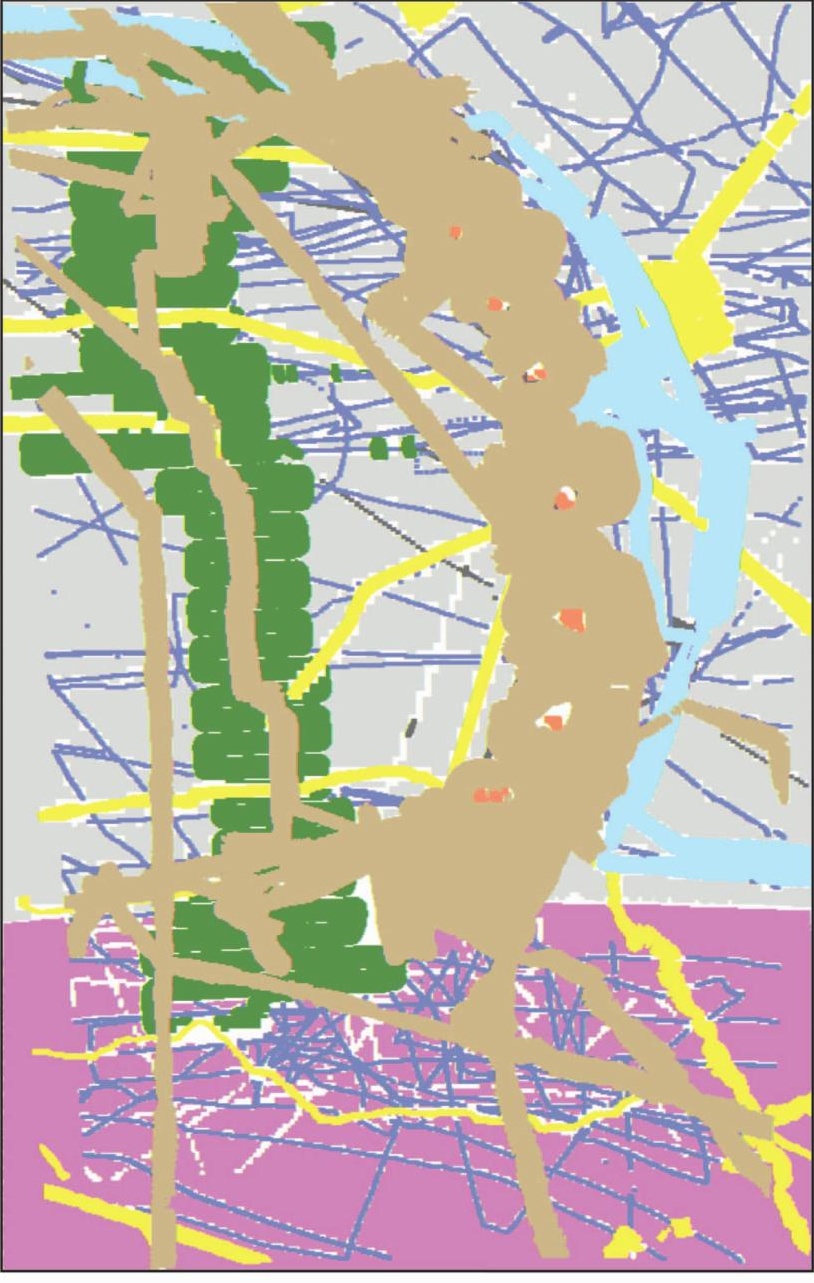

$\square$ BAS Multibeam

AWI Multibeam

MARUM

Multibeam

BAS MR1 towed

BAS Singlebeam

IBCSO

Fisheries Singlebeam

GEBCO 


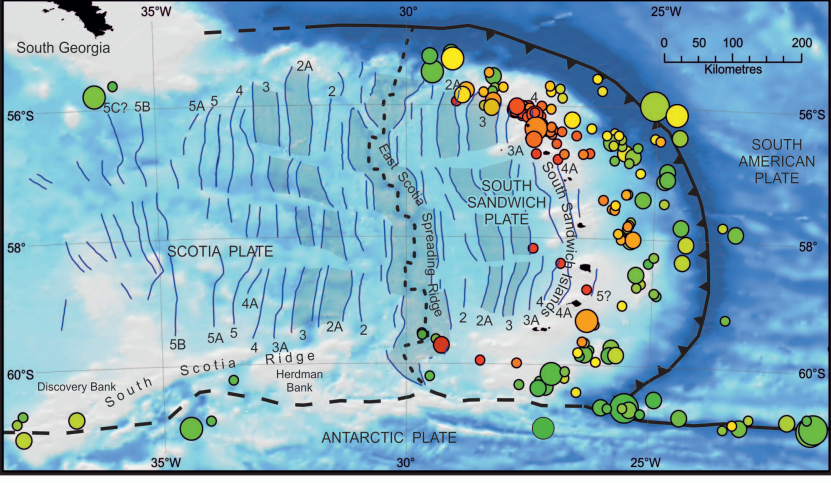

Plate margin with known location

Plate margin with inferred location
Spreading ridge

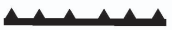

Subduction zone
Earthquake magnitude

- 5.5-6.0

O $\quad 6.0-6.5$

( $6.5-7.0$

7.0-7.5 


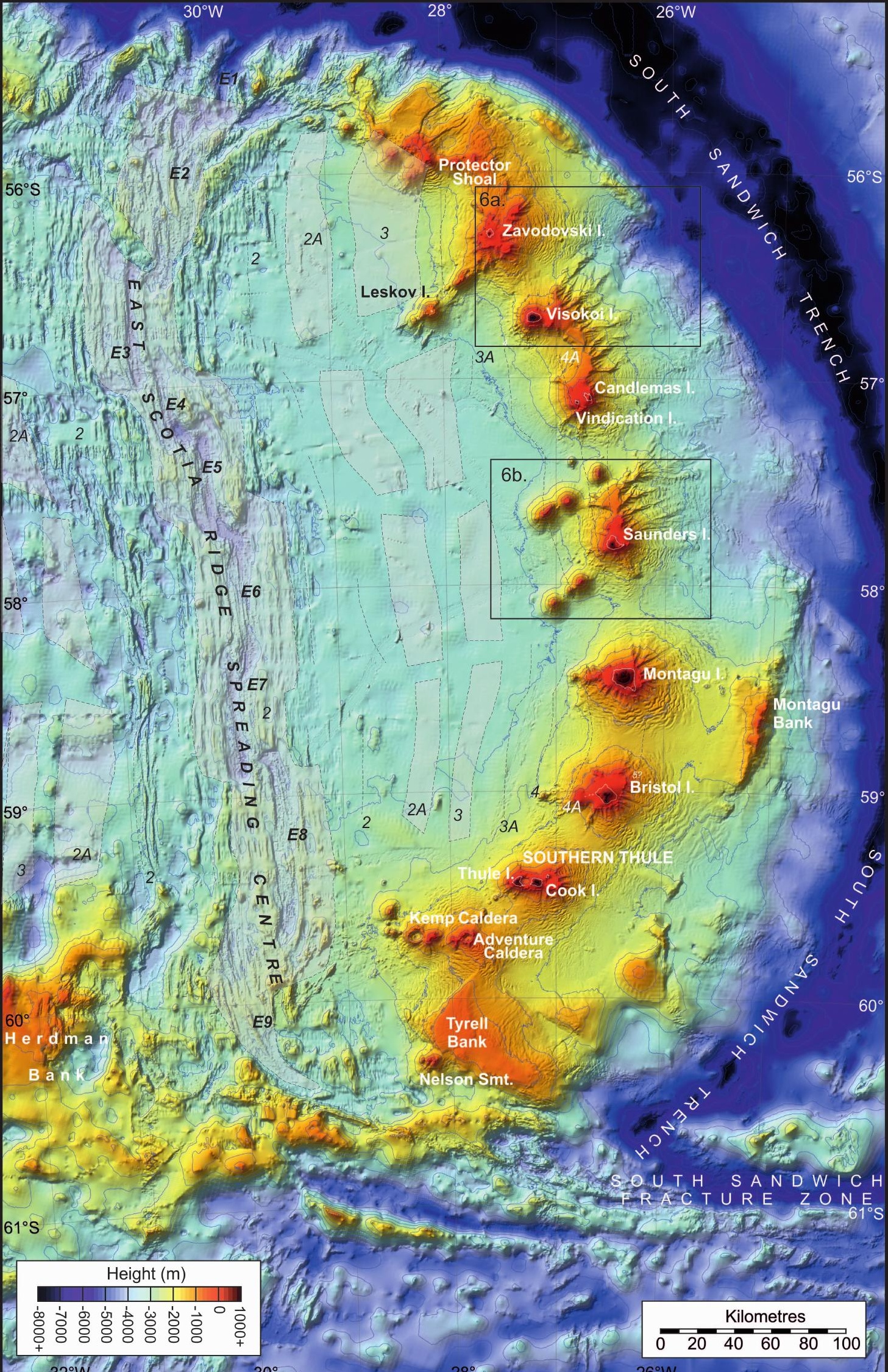




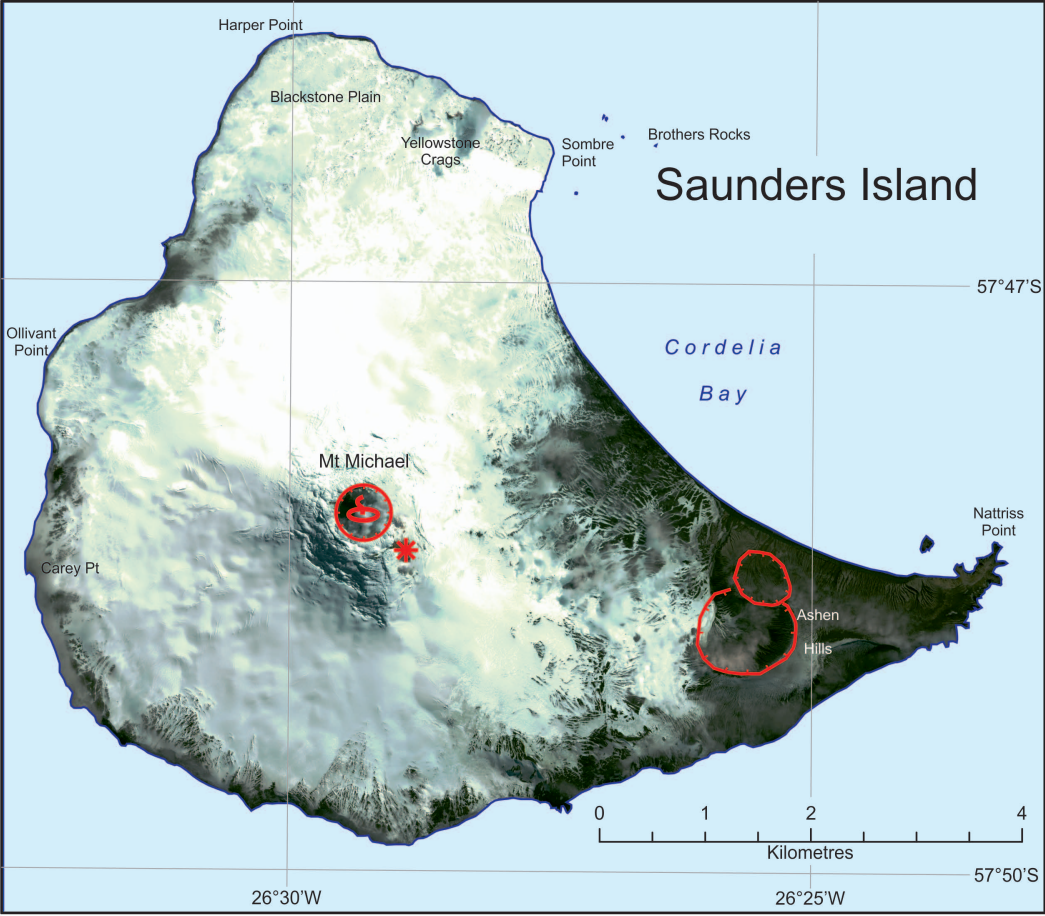

\section{Volcanic symbols}

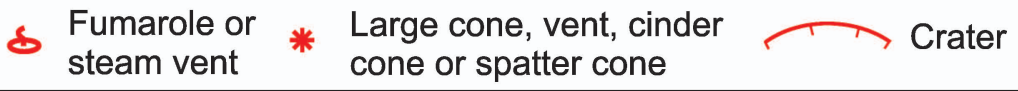



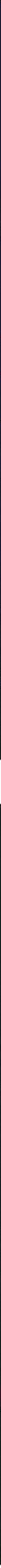

Height $m$

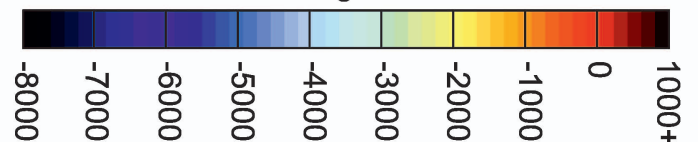

